Вісник Харківського національного університету імені В.Н. Каразіна Серія "Математика, прикладна математика і механіка" Том 88,2018 , с. $44-57$

УДК 517.9:532
Visnyk of V.N.Karazin Kharkiv National University Ser. "Mathematics, Applied Mathematics and Mechanics"

Vol. 88, 2018, p. 44-57

DOI: $10.26565 / 2221-5646-2018-88-05$

\title{
Mathematical modeling of bioactive arterial wall
}

\author{
H. N. Solovyova ${ }^{1}$, N. N. Kizilova ${ }^{2}$ \\ ${ }^{1}$ Kharkov National Politechnical University "KhPI Kharkov, \\ 2 Kirpichova Street, 61002, Ukraine \\ ${ }^{2}$ V.N. Karazin Kharkiv National University, Kharkov, \\ 4 Svobody Square, 61022, Ukraine \\ helenfilippova@yahoo.co.uk,n.kizilova@gmail.com
}

Biological tissues and their artificial substitutes are composed by different fibers and possess complex viscoelastic properties. Here the most popular 3-element and 5-element rheological models of human soft tissues as viscoelastic bodies are considered accounting for the time delay between the load and mechanical respond of the material.The obtained data compared to the experimental curves got on the vessel wall and heart tissues.

Keywords: active biomaterials; visoelastic fluids; rheology; mathematical modelling.

Соловйова О. М., Кізілова Н. М. Математичне моделювання біоактивної артеріальної стінки. Біологічні тканини та їх штучні замінники складаються з різних волокон і мають складні в'язко-пружні властивості. В роботі розглянуті найпопулярніші 3-елементні та 5-елементні реологічні моделі м'яких тканин людини як в'язкопружні тіла, що враховують затримку часу між навантаженням та механічним відгуком матеріалу. Отримані дані порівнювались з експериментальними кривими отриманними на стінкці судин і тканинах серця.

Ключові слова: активні біоматеріали; в'язкопружні рідини; реологія; математичне моделювання.

Соловьева Е. Н., Кизилова Н. Н. Математическое моделирование биоактивной артериальной стенки. Биологические ткани и их искусственные заменители состоят из разных волокон и характеризуются сложными вязкоупругими свойствами. В работе рассматриваются наиболее популярные 3-элементные и 5-элементные реологические модели мягких тканей человека как вязкоупругих тел, учитывающие запаздывание во времени между нагрузкой и механическим ответом материала. Полученные данные сравнивались с экспериментальными кривыми, полученными на стенках кровеносных сосудов и тканях сердца.

Ключевые слова: активные биоматериалы; вязкоупругие жидкости; реология; математическое моделирование.

2010 Mathematics Subject Classification: 35K05; 76Z05.

\section{Introduction}

Bioactive materials are biological tissues or artificial materials that can perform a mechanical work at the expense of chemical reactions, conformational

(c) H. N. Solovyova, N. N. Kizilova, 2018 
changes, micro- and mesostructure formation and remodeling [1]. Such materials are abound in biological organisms like skeletal, smooth and cardiac muscles, flagella and cilia in bacteria, cytoskeleton and molecular motors in the cells [2]. Recently novel artificial solid and liquid materials with complex chemical and physical properties, reinforced by the micro- and nanofibers or other inclusions, porous materials with active reaction on the mechanical, chemical, electrical stimuli have appeared [3]. The external signals evoke contraction of the fibers, remodeling of the internal micro/mesostructure, produce phase transitions, fluid flows, mass and heat redistribution and related physical phenomena [4]. During the last years a novel concept of biological active fluids (BAF) has been elaborated and developed $[3,5]$. Initially concentrated suspensions of biological cells were considered as active biofluids, but nowadays the artificial suspensions and emulsions of colloidal particles, fibers and other inclusions that are able to change their shape, size or/and physical properties depending on the nature and amplitude of the external signal have been designed and studies. BAFs are used in the microbiological reactors for the chemical, pharmaceutical, energetic applications. They are also promising compounds of modern microfluidic units, labs-on-a-chip, fuel cells and other micro/nano technologies $[3,4,5]$. For instance, in the new version of smart Apple watch ver.4 BAF is used for visualization of information taken from the human body via the chemical/electrical skin signaling.

The first mathematical model of the active biological material was proposed by A.Hill in the form of a hyperbolic relationship between the tension (or load) $\mathrm{F}$ in the muscle and its active velocity of contraction $\mathrm{v}$ :

$$
(F+a)(v+b)=\left(F_{0}+a\right) b,
$$

where $F_{0}$ is the maximum isomeric tension/load in the muscle, a and b are coefficients. It describes the $1 \mathrm{D}$ contraction in the term of the dissipation function approach to the active muscular work [6].

The corresponding continual equation for 1D muscular tonus of blood vessels has been postulated in the form [7].

$$
\tau_{1} \frac{\partial \sigma}{\partial t}+\sigma=E \varepsilon+\tau_{2} \frac{\partial \varepsilon}{\partial t}+\lambda
$$

where $\sigma$ and $\varepsilon$ are stress and strain, $\tau_{1}, \tau_{2}$ are the relaxation times, $\lambda$ is a control parameter.

In the biological materials the control over the stress-strain relation is provided by local concentrations of some chemicals ( $\mathrm{Ca}, \mathrm{NO})$ released by special cells. Therefore, the rheological equation (1) with the source term $\lambda=\lambda\left(C_{C a}, C_{N O}, \ldots\right)$ must be completed by the corresponding balance equations for the concentrations $\left\{C_{j}\right\}_{j=1}^{n}[8]$.

A simple model for the active blood vessel with changing radius $R(\langle\sigma\rangle,\langle p\rangle)$, where $\langle\sigma\rangle$ and $\langle\sigma\rangle$ are the averaged shear stress and pressure in the vessel postulated in the form

$$
\dot{R}(t)=f\left(R, \sigma\left(t-\tau_{1}\right), p\left(t-\tau_{2}\right), \ldots\right)
$$


accounting for the delay in response of the corresponding stress and pressure receptors in the vessel wall, and completed by the Poiseuille flow based equations for the shear stress and pressure has been proposed in [9]. The solution was sought in the form of small excitations $R=R_{0}+R^{\prime}, \sigma=\sigma_{0}+\sigma^{\prime}, p=p_{0}+p^{\prime}$, $\left\{R^{\prime}, \sigma^{\prime}, p^{\prime}\right\}=\left\{R_{a}, \sigma_{a}, p_{a}\right\} e^{\lambda t}$ where the subscripts 0 and a relate to the steady state and amplitudes. The stability condition $\operatorname{Re}(\lambda)<0$ led to some conditions on the function $f(R, \ldots)$ and its derivatives.

The model $(1)$ has been generalized in $[10,11]$ for the nonlinear viscoelastic Kelvin-Voigt body

$$
\tau_{2} \frac{d \varepsilon}{d t}+\varepsilon=F(\sigma)+\tau_{1} \frac{d \sigma}{d t}+\Lambda(C)
$$

where $F(\sigma)$ is the passive law function, $\Lambda(C)$ is the control function via the concentration(s) of active chemical components.

In this paper a comparative study of the existing discrete rheological models and their continual analogies with the experimental data is carried out in order to conduct the identification of material parameters of the models on a minimal set of experimental measurements. The loading and relaxation curves for those models at the isometric, isotonic and oscillatory experiments have been studied in $[12,13]$. Since in the experiments with soft biological tissues the dynamical loads at different extension rates are usually used, the corresponding mathematical models are needed for the adequate treatment and analysis of the experimental data.

\section{Rheological model without regard for the tima delay.}

\subsection{Three element model with one active element.}

The model is represented (Fig. 1 a) by two elastic spring elements correspondent to the passive elastic behavior of the outer $E_{1}$ and internal $E_{2}$ collagen structures, one viscous component $\mu$, and the active element that produces immediate mechanical response $f=k_{1} \varepsilon+k_{2} \dot{\varepsilon}$ proportional to the local strain $\varepsilon$ and strain rate $\dot{\varepsilon}, \dot{*} \equiv d * / d t$. The model is a modified viscoelastic Zener model with one active element. Passive Zener model is widely used for interpretation of the experimental data obtained on single cells by atomic force microscopy or optical tweezers $[14,15]$. The rheological equation for the model is [13] :

$$
\begin{gathered}
\left(k_{2}+\mu\right) \dot{\sigma}+\left(k_{1}+E_{2}\right) \sigma=E_{1}\left(E_{2}+k_{1}\right) \varepsilon+ \\
\left(E_{1}\left(k_{2}+\mu\right)+\left(E_{2}+k_{1}\right) \mu\right) \dot{\varepsilon}+\mu k_{2} \ddot{\varepsilon} .
\end{gathered}
$$

In the experiments with muscles a linear extension

$$
\varepsilon(t)=k t
$$

with a constant extension rate $\dot{\varepsilon}=k$ is applied. Then the resulting rheological curves $\sigma(t)$ can be obtained from (4) after substitution (5) with the initial conditions

$$
\sigma\left(t_{0}\right)=\sigma_{0}
$$


and compared to the experimental curves $\sigma_{\text {exp }}(t)$ measured by the stress sensors.

Solution of (4)-(6) is

$$
\sigma(t)=k \mu+E_{1} k t+\left(\sigma_{0}-k \mu\right) \exp \left(-\frac{E_{2}+k_{1}}{k_{2}+\mu} t\right) .
$$

When the external strain (5) is applied until the stress

$$
\sigma_{1}=\sigma\left(t_{1}\right)
$$

at some $t=t_{1}$ is reached and then the material got released, the relaxation curve $\sigma_{\text {rel }}(t)$ can be obtained from (4) at $\varepsilon=0$ with initial condition (8) in the form

$$
\sigma_{r e l}(t)=\sigma_{1} \exp \left(-\frac{E_{2}+k_{1}}{k_{2}+\mu}\left(t-t_{1}\right)\right)
$$

For the dynamical experiments with a linear growing stress $\sigma(t)=k_{0}+k t$ applied to the viscoelastic body, the corresponding solution of (4) with initial conditions

$$
\varepsilon\left(t_{0}\right)=0, \quad \dot{\varepsilon}\left(t_{0}\right)=0
$$

is

$$
\begin{gathered}
\varepsilon(t)=\frac{\left(E_{1} k_{0}-\mu k\right) \mu k_{2}}{E_{1}^{2}}\left(1-\exp \left(-\lambda_{2} t\right)\right)+\frac{\mu k k_{2}}{E_{1}} t+ \\
C_{3}\left(\left(E_{1} k_{0}-\mu k\right) \mu k_{2} \lambda_{2}+\mu E_{1} k k_{2}\right) \frac{\left(\exp \left(-\lambda_{1} t\right)-\exp \left(-\lambda_{2} t\right)\right)}{\left(\lambda_{1}-\lambda_{2}\right) E_{1}^{2}}
\end{gathered}
$$

where

$$
\begin{aligned}
& \lambda_{1,2}=\frac{1}{2}\left( \pm \sqrt{A^{2}-4 B}-A\right), \quad A=\frac{\left(E_{2}+k_{1}\right) \mu+\left(k_{2}+\mu\right) E_{1}}{\mu k_{2}}, \\
& B=\frac{E_{1}\left(E_{2}+k_{1}\right)}{\mu k_{2}} .
\end{aligned}
$$

The corresponding relaxation curve for the strain can be obtained from (4) in the similar way and has the form

$$
\varepsilon_{r e l}(t)=\varepsilon_{1}+\frac{\lambda_{1} \varepsilon_{1}+\dot{\varepsilon}_{1}}{\lambda_{1}-\lambda_{2}} \exp \left(-\lambda_{2} t\right)-\frac{\lambda_{2} \varepsilon_{1}+\dot{\varepsilon}_{1}}{\lambda_{1}-\lambda_{2}} \exp \left(-\lambda_{1} t\right),
$$

where $\varepsilon_{1}=\varepsilon\left(t_{1}\right), \dot{\varepsilon}_{1}=\dot{\varepsilon}\left(t_{1}\right), t_{1}$ is the time instant when the sample got released from the load $(\sigma=0)$.

The stress relaxation curve (3) exhibits simple exponential decay with time, while the strain relaxation demonstrates two-step dynamic with initial faster and final slower decays that is more proper to the biological materials. For the constant loads $\sigma=\sigma^{*}=$ const and $\varepsilon=\varepsilon^{*}=$ const the expressions $(7),(9),(11),(12)$ give the corresponding curves obtained in [13].

Dynamical experiments on the model (4) with a periodical load $\sigma(t)=\sigma_{0} e^{i \omega t}$, where $\omega$ is the frequency of the load produce the oscillations of strain in the form

$$
\varepsilon=\varepsilon_{0} e^{i(\omega t+\psi)},
$$


where $\varepsilon_{0}=A \sigma_{0}, A$ and $\psi$ are the amplitude and phase shift which are complex functions of all the material parameters of the model. The expressions are not presented here for brevity. The corresponding simpler expressions for the case $k_{1}=0, k_{2}=0$ are given in [13].

Viscoelastic properties and active reaction of the material lead to the phase shift between the applied load and produced strain oscillations. As it is known from vast experimental literature, the shift is negligible in the healthy tissues and noticeable in the case of pathologies connected with water accumulation in the tissues (oedema) and the active respond of the material to the applied load and its time dependent parameters [16].

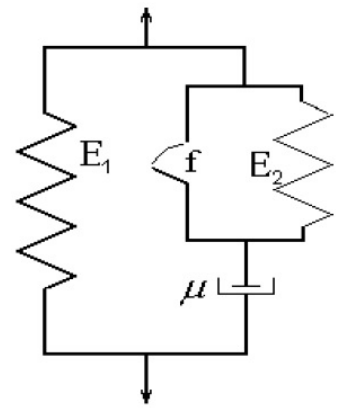

a

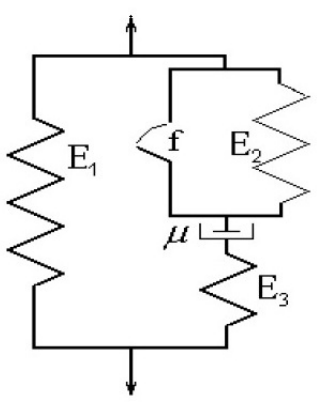

$\mathrm{b}$

Fig. 1: Three element (a) and five element (b) rheological models with one active element.

\subsection{Five element model with one active element.}

The more detailed five element rheological model (Fig.1b) of an active biological material like muscles is described by the corresponding rheological equation [13]

$$
\begin{gathered}
\mu k_{2} \ddot{\sigma}+\left(\left(k_{2}+\mu\right) E_{3}+\left(E_{2}+k_{1}\right) \mu\right) \dot{\sigma}+E_{3}\left(k_{1}+E_{2}\right) \sigma= \\
E_{1} E_{3}\left(E_{2}+k_{1}\right) \varepsilon+\left(E_{1} E_{3}\left(k_{2}+\mu\right)+\left(E_{2}+k_{1}\right)\left(E_{1}+E_{3}\right) \mu\right) \dot{\varepsilon}+ \\
\mu\left(E_{1}+E_{3}\right) k_{2} \ddot{\varepsilon},
\end{gathered}
$$

where $E_{1}, E_{2}, \mu, k_{1}, k_{2}$ have the same meaning as in (4), and $E_{3}$ corresponds to passive elastic tissues which are in a series connections with the contracting muscle fibers. This model better explains the rheological behavior of the stresses, over trained or diseased tissues. Normal circular muscles in mammals as well as active contracting structures in insects and mollusks also have serial inclusions of passive tissues [16].

The isotonic, isometric and oscillatory experiments with model (7) have been studied in $[12,13]$. Let us consider the linear extension in the form $(5)$ applied to 
(14) with the same initial conditions (6); then to solution reads

$$
\begin{aligned}
& \sigma(t)=C+E_{1} k t+\frac{\dot{\sigma}_{0}+\lambda_{2}\left(\sigma_{0}-C\right)-E_{1} k}{\lambda_{2}-\lambda_{1}} \exp \left(-\lambda_{1} t\right)+ \\
& C_{4} \frac{E_{1} k-\dot{\sigma}_{0}-\lambda_{1}\left(\sigma_{0}-C\right)}{\lambda_{2}-\lambda_{1}} \exp \left(-\lambda_{2} t\right)
\end{aligned}
$$

where

$\sigma_{0}=\sigma(0), \quad \dot{\sigma}_{0}=\dot{\sigma}(0)$,

$\lambda_{1,2}=\frac{1}{2}\left(A \pm \sqrt{A^{2}-4 B}\right), \quad A=\frac{\left(\left(k_{2}+\mu\right) E_{3}+\left(E_{2}+k_{1}\right) \mu\right)}{\mu k_{2}}$,

$B=\frac{E_{3}\left(k_{1}+E_{2}\right)}{\mu k_{2}}, C=\frac{\left(E_{2}+k_{1}\right)^{2}\left(\left(E_{1}+E_{3}\right) E_{3}-E_{1} E_{3} k\right)}{k_{2}}$.

For the linear growing stress $\sigma(t)=k_{0}+k t$ the solution of (14) with initial conditions (10) is

$$
\varepsilon(t)=C+\frac{k}{E_{1}} t+\frac{k / E_{1}+\lambda_{2} C}{\lambda_{1}-\lambda_{2}} \exp \left(-\lambda_{1} t\right)-\frac{k / E_{1}+\lambda_{1} C}{\lambda_{1}-\lambda_{2}} \exp \left(-\lambda_{2} t\right),
$$

where

$\lambda_{1,2}=\frac{1}{2}\left( \pm \sqrt{A^{2}-4 B}-A\right), \quad A=\frac{\left(E_{1} E_{3}\left(k_{2}+\mu\right)+\left(E_{2}+k_{1}\right)\left(E_{1}+E_{3}\right) \mu\right)}{\mu\left(E_{1}+E_{3}\right) k_{2}}$,

$B=\frac{E_{1} E_{3}\left(E_{2}+k_{1}\right)}{\mu\left(E_{1}+E_{3}\right) k_{2}}, \quad C=\frac{\left(\left(k_{2}+\mu\right) E_{3}+\left(E_{2}+k_{1}\right) \mu\right) k+E_{3}\left(k_{1}+E_{2}\right) k_{0}}{E_{1} E_{3}\left(E_{2}+k_{1}\right)}$.

The corresponding relaxation curves for the five element model can be also written in the forms (9) and (12) accordingly. Despite the tree element model, the five element one exhibits the two time relaxation processes for both stress and strain relaxations that is more common for the biological tissues especially in the pathological state $[14,15,16]$.

Dynamical experiments with the model also produce a phase shift between the applied oscillating load and the resulting oscillations of the measured strain in the form of (13) with different more complex expressions for the amplitude $A$ and phase shift $\psi$.

\section{Rheological models with time delay.}

\subsection{Three element model.}

The active respond of the biological tissues is determined by reactions of the corresponding receptors or mediated by chemical reactions [16]. This response can come with some time delay or even two times in the case of different sensors; therefore, the active delayed response (2) can be written in the form of the control function

$$
f(t)=k_{1} \varepsilon\left(t-\tau_{1}\right)+k_{2} \dot{\varepsilon}\left(t-\tau_{2}\right),
$$

where $\tau_{1}, \tau_{2}$ are the delays for the strain and strain rate receptors. 
Then instead of (4) one can obtain the following rheological equation

$$
\begin{gathered}
\mu \dot{\sigma}(t)+E_{2} \sigma(t)=E_{1} E_{2} \varepsilon(t)+ \\
\mu\left(E_{1}+E_{2}\right) \dot{\varepsilon}(t)+\mu\left(k_{1} \dot{\varepsilon}\left(t-\tau_{1}\right)+k_{2} \ddot{\varepsilon}\left(t-\tau_{2}\right)\right) .
\end{gathered}
$$

For the dynamical experiments with a linear growing stress the solution of the resulting equation

$$
\begin{gathered}
\mu\left(E_{1}+E_{2}\right) \dot{\varepsilon}(t)+E_{1} E_{2} \varepsilon(t)+\mu k_{2} \ddot{\varepsilon}\left(t-\tau_{2}\right)+\mu k_{1} \dot{\varepsilon}\left(t-\tau_{1}\right)= \\
\mu k+E_{2}\left(k_{0}+k t\right) .
\end{gathered}
$$

can be found in the form

$$
\varepsilon(t)=\varepsilon_{0} e^{-\lambda t}+\frac{k}{E_{1}} t+\frac{E_{1} k_{0}-k \mu}{E_{1}^{2}}\left(1-e^{-\lambda t}\right)
$$

where $\varepsilon_{0}=\varepsilon(t)$ and the constant $\lambda$ is a solution of the transcendental equation similar to [9]:

$$
E_{1} E_{2}=\lambda \mu\left(E_{1}+E_{2}\right)+\mu k_{1} \lambda e^{\lambda \tau 1}-\mu k_{2} \lambda^{2} e^{\lambda \tau 2}
$$

For the dynamical experiments with oscillating external load $\sigma(t)=\sigma_{0} e^{i \omega t}(18)$ gives the following non-uniform ODE with delay

$$
\begin{gathered}
\mu\left(E_{1}+E_{2}\right) \dot{\varepsilon}(t)+E_{1} E_{2} \varepsilon(t)+\mu\left(k_{1} \dot{\varepsilon}\left(t-\tau_{1}\right)+k_{2} \ddot{\varepsilon}\left(t-\tau_{2}\right)\right)= \\
\sigma_{0} e^{i \omega t}\left(E_{2}+i \omega \mu\right)
\end{gathered}
$$

Solution of (22) can be found as a superposition of the oscillating and nonoscillating terms

$$
\varepsilon(t)=A \sigma_{0}\left(e^{i(\omega t+\psi)}-e^{i \psi-\lambda t}\right)
$$

where

$A=\sqrt{\left(E_{2} f_{1}+\omega^{2} \mu f_{2}\right)^{2}+\omega^{2}\left(\mu f_{1}+E_{2} f_{2}\right)^{2}}, \psi=\operatorname{atan}\left(\frac{\omega\left(\mu f_{1}+E_{2} f_{2}\right)}{E_{2} f_{1}+\omega^{2} \mu f_{2}}\right)$,

$f_{1}=E_{1} E_{2}-\mu k_{2} \omega^{2} \cos \left(\omega \tau_{1}\right)+\omega \mu k_{1} \sin \left(\omega \tau_{2}\right)$,

$f_{2}=\mu\left(E_{1}+E_{2}\right)+\omega \mu k_{2} \sin \left(\omega \tau_{1}\right)+\mu k_{1} \cos \left(\omega \tau_{2}\right), \lambda$ is the solution of the transcendental equation $E_{1} E_{2}-\lambda \mu\left(E_{1}+E_{2}\right)=\mu\left(\lambda k_{1} e^{-\lambda \tau 1}-\lambda^{2} k_{2} e^{-\lambda \tau 2}\right)$.

\subsection{Five element model.}

For the five element model (Fig.1b) with delay instead of (13) one can obtain the following rheological equation

$$
\begin{gathered}
\mu\left(E_{1} E_{2}+E_{1} E_{3}+E_{2} E_{3}\right) \dot{\varepsilon}+E_{1} E_{2} E_{3} \varepsilon+ \\
E_{3} \mu\left(k_{1} \dot{\varepsilon}(t-\tau 1)+k_{2} \ddot{\varepsilon}(t-\tau 2)\right)=E_{2} E_{3}\left(k_{0}+k t\right)+\mu\left(E_{2}+E_{3}\right) k
\end{gathered}
$$


that has the solution in the form

$$
\varepsilon(t)=\varepsilon_{0} e^{-\lambda t}+\frac{k}{E_{1}} t+\frac{E_{1} E_{2} k_{0}-\mu k\left(E_{2}+k_{1}\right)}{E_{1}^{2} E_{2}}
$$

where $\varepsilon_{0}=\varepsilon(t)$ and the constant $\lambda$ is a solution of the transcendental equation

$$
E_{1} E_{2} E_{3}=\mu\left(E_{1} E_{2}+E_{1} E_{3}+E_{2} E_{3}\right) \lambda+E_{3} \mu k_{1} \lambda e^{\lambda \tau 1}-E_{3} \mu k_{2} \lambda^{2} e^{\lambda \tau 2}
$$

For the dynamical experiments with oscillating external load the corresponding solution of $(24)$ is similar to (23).

\section{Numerical results and discussions.}

Numerical computations on (7), (9),(11),(12), (15), (16) have been carried out with following model parameters: $E_{1,2,3}=10^{5}-10^{8} \mathrm{~Pa}, \mu=1-10^{3} \mathrm{~Pa} \cdot \mathrm{s}$, $\tau_{1,2}=10-50 \mathrm{~s}, k_{1}=10^{6}-10^{7} \mathrm{~Pa}, k_{2}=10-100 \mathrm{~Pa} \cdot \mathrm{s}$. The results have been plotted in the non-dimensional form using the characteristic values $\sigma^{*}=10^{4} \mathrm{~Pa}$, $t^{*}=5 \mathrm{~min}$. The load was applied at $0<t<10$ and then relaxed at $t>10$.

Typical time dependencies of the measured non-dimensional stress over the non-dimensional time $\sigma(t)$ are presented in Fig.1 for the three-element (Fig.2a) and five-element (Fig.2b) rheological models with one active element without delay. In comparison to the isometric experiments [13] both models exhibit faster dynamics of the stress growth due to the linear terms in $(7),(15)$. The threeelement model has the only relaxation time $\lambda^{-1}$ that is a complex combination of the model parameters. Therefore, identification of the parameters $E_{1} k$ and $\mu k$ can be carried out on the growing part of the $\sigma(t)$ curve (Fig.2a) and only the combinations of the parameters can be determined. Then the value $\lambda^{-1}=\left(k_{2}+\mu\right) /\left(E_{2}+k_{1}\right)$ can be identified on the relaxing part of the same curve. Knowing the combinations $E_{1} k$ and $\mu k$, the values, the parameters $E_{2}, k_{1}, k_{2}$ can not be separately determined. As it was shown in [13] in the case of a passive model the oscillatory experiments give an opportunity to determine all the material parameters separately. In the case of the active material with two more unknown material parameters $k_{1}, k_{2}$ even the dynamical experiments will not allow determination of all the parameters. In the case of biological materials some additional chemical treatment changing elasticity of the fibers (i.e. $E_{1}, E_{2}$ or $E_{3}$ ) could be useful [14, 15] .

The five-element model demonstrates two-phase relaxation with different relaxation times $\lambda_{1}^{-1}, \lambda_{2}^{-1}$ that correspond to the bigger and smaller positive roots of the related quadratic equation in (15). This is an essential feature of dynamical behavior of complex viscoelastic materials even without any active response [13]. Again, in the case of one active element the identification of the material parameters is somehow complicated, because all the parameters are introduced in the values $\lambda_{1}^{-1}, \lambda_{2}^{-1}$ in certain combinations only. The dynamical experiments give an opportunity for complete identification only for a passive five-element material [13]. 


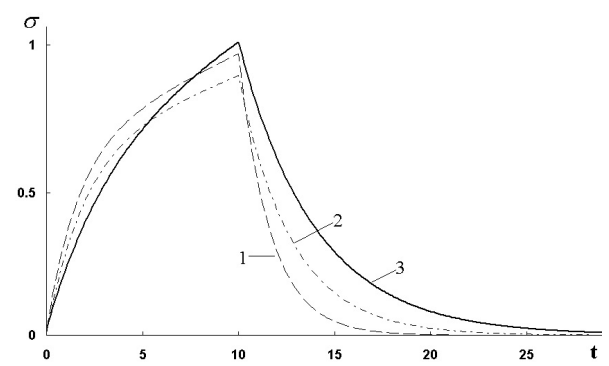

a

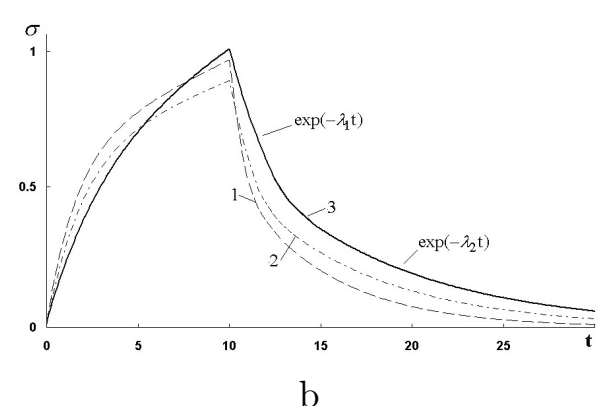

$\mathrm{b}$

Fig. 2: The non-dimensional stress curves for the dynamical experiments (linear load and relaxation) for the three-element (a) and five-element (b) models for $E_{1}=10^{6} \mathrm{~Pa}, \mu=100 \mathrm{~Pa} \cdot s, k_{1}=10^{6} \mathrm{~Pa}, k_{2}=100 \mathrm{~Pa} \cdot \mathrm{s}$; the curves 1-3 correspond to $E_{2}=10^{5} ; 5 \cdot 10^{5} ; 10^{6} \mathrm{~Pa}$; the values for $E_{3}$ has been computed to get similar dynamics of the stress increase during the load period.

The influence of the time delay is illustrated by Fig.3a,b. Here the results of experiments with load and relaxation at different load rates $\mathrm{k}=0.1 ; 1.10$ have been computed. As it is known from biomechanics of soft tissues, the larger stresses and elongations can be achieved at lower loading rates, both stress and strain rates [17] . Similar dynamics is visible on the five-element models without (Fig.3a) and with time delay (Fig.3b). When the delay is absent (passive material), the changes from the load to relaxation are resented by sharp changes in the tangents to the loading and relaxation curves (Fig.3a). The delay prolongs the 'respond' of the material after the transition from load to relaxation and the correspondent transition is presented as a smooth line for all the strain rates applied (Fig.3b). This smoothness is almost insignificant at short delays, and for visibility purposes it has been taken quite large comparative to those detected in experiments with active muscles [17].

An alternative representation of the rheological representation of the cycling loading-discharge experiments is usually presented by the stress-strain $\sigma(\varepsilon)$ or stress-strain rate $\sigma(\dot{\varepsilon})$ curves [17]. The discharge curve is always located below the corresponding load curve because of some energy dissipated during the deformations. Some sets of experimental data with aortic wall and muscles [17] have been chosen for testing the studied 3-element and 5-element models. Due to different amounts of elastin and collagen in the vessel wall and muscles, the $\sigma(\varepsilon)$ curves exhibit high elongation at lower loads when the actin fibers participate in the deformation, followed by smaller elongation at higher loads when the more rigid collagen fibers participate in the deformation (Fig.4a). The differences between the corresponding load and discharge curves in each cycle of load are small because of the high efficiency of the muscle work and negligible energy dissipation. Based on the experimental data, the parameters of the 3-element and 5-element models without delay have been identified by the least square method. As it is shown by Fig.4a, the 3-element model when being well matched to the low loads does not correspond to the dynamics at the high loads, for both models (without or 
with delay). The 5-element model better correspond to the experimental data. The model without delay being well matched to the low loads, underestimate the stress, while the model with delay is overestimate it.

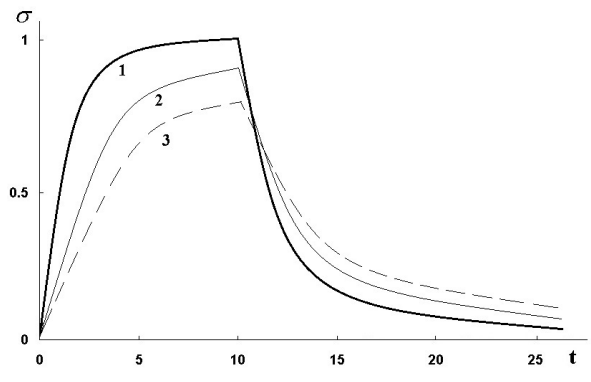

a

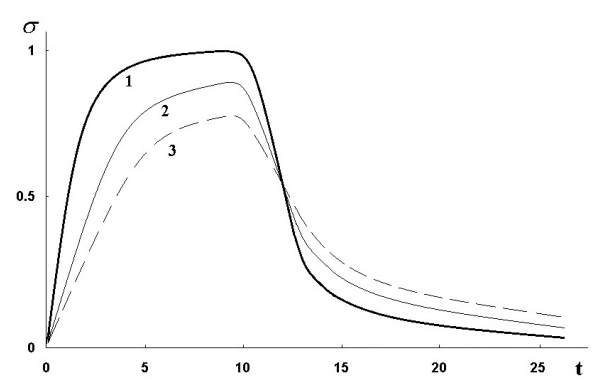

b

Fig. 3: The non-dimensional stress curves for the dynamical experiments for the five-element model without (a) and with (b) delay; the material parameters are the same as in Fig.2; the curves 1-3 correspond to $k=0.1 ; 1 ; 10$.

In Fig.4b the load-relaxation curves computed on the rheological parameters identified from the experimental curves (Fig.4a) on the 5-element models are presented. The curves $1-3$ correspond to the same strain rates $\mathrm{k}=0.1,1,10$, while the solid lines depict the model without delay while the thin lines shows the relaxation curves for the 5-element model with delay. The last model shows again the smoother dynamics, because at the beginning of the relaxation the delay in the active respond influences the initial part of the relaxation curves. Moreover, the models without/with delay again slightly over/underestimate the reaction of the active material to both load and relaxation.
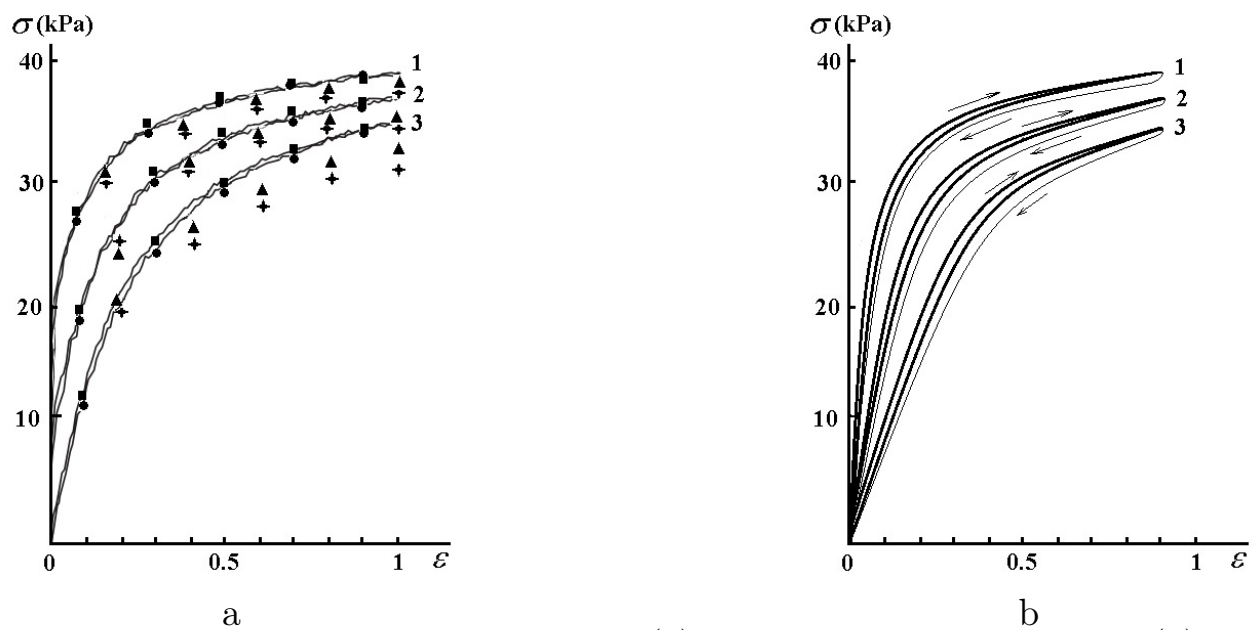

Fig. 4: The dimensional experimental $\sigma(\varepsilon)$ curves for the aortic wall (a) heart tissues (b); the curves 1-3 correspond to the strain rates $0.1,1,10 \mathrm{~s}^{-1}$, the symbols a and $\Delta$ correspond to 3-element models without and with delay, the symbols and $\bullet$ correspond to 5-element models without/with delay. 
Similar results have been obtained for the experimental data (Table 1) measured on the heart tissues [18] . It was shown, a five-element rheological model better corresponds to the experimental data than the standard three-element model [18] . The model differs from one presented in (Fig.1b) by the second viscous element $\left(\mu_{2}\right)$ instead of the active element used in our model. It means, the 5-element model in [18] corresponds to our 5-element model without delay and $k_{1}=0$. The experimental data have been obtained on 10 samples of human heart tissues and exhibit significant scatter. The identified values of the model [18] parameters correspondent to our model are given in Table 1. The numerical data correspond to the mean experimental values. The comparative study reveals very good agreement between the experimental data measured on heart tissues and our modeling results (Fig.4b).

Table 1: Averaged measurement data for the material parameters of the 5-element rheological model [18] and our model presented in (Fig.1b); the Young modules and viscosity are measured in $M P a$ and $P a \cdot s$ respectively.

\begin{tabular}{|l|l|l|l|l|l|l|l|l|l|l|}
\hline & \multicolumn{5}{|c|}{ Experimental data } & \multicolumn{5}{c|}{ Computed data } \\
\hline$\varepsilon$ & $E_{1}$ & $E_{2}$ & $E_{3}$ & $\mu_{1}$ & $\mu_{2}$ & $E_{1}$ & $E_{2}$ & $E_{3}$ & $\mu_{1}$ & $\mu_{2}$ \\
\hline 0.1 & $0.92 \pm$ & $0.31 \pm$ & $0.28 \pm$ & $32.2 \pm$ & $18.4 \pm$ & 0.88 & 0.26 & 0.22 & 30.8 & 18.1 \\
& 0.80 & 0.25 & 0.22 & 23.8 & 16.0 & & & & & \\
\hline 0.2 & $1.69 \pm$ & $0.49 \pm$ & $0.38 \pm$ & $55.8 \pm$ & $25.3 \pm$ & 1.67 & 0.46 & 0.31 & 54.6 & 24.9 \\
& 1.40 & 0.36 & 0.27 & 38.9 & 19.0 & & & & & \\
\hline 0.3 & $2.50 \pm$ & $0.73 \pm$ & $0.58 \pm$ & $83.4 \pm$ & $37.5 \pm$ & 2.44 & 0.69 & 0.52 & 81.8 & 36.9 \\
& 1.86 & 0.51 & 0.37 & 58.6 & 24.6 & & & & & \\
\hline 0.4 & $3.29 \pm$ & $0.97 \pm$ & $0.8 \pm$ & $109.9 \pm 49.1 \pm$ & 3.25 & 0.93 & 0.74 & 108.4 & 48.5 \\
& 2.11 & 0.59 & 0.44 & 68.6 & 26.1 & & & & & \\
\hline 0.5 & $4.07 \pm$ & $1.23 \pm$ & $1.11 \pm$ & $143.9 \pm 65.0 \pm$ & 4.02 & 1.19 & 1.06 & 142.1 & 64.3 \\
& 2.25 & 0.71 & 0.54 & 94.8 & 31.2 & & & & & \\
\hline 0.6 & $4.89 \pm$ & $1.44 \pm$ & $1.25 \pm$ & $165.3 \pm$ & $77.2 \pm$ & 4.83 & 1.40 & 1.21 & 163.9 & 76.3 \\
& 2.40 & 0.58 & 0.53 & 6.76 & 3.04 & & & & & \\
\hline
\end{tabular}

\section{Conclusions.}

Based on different experimental data, it was shown the 5-element rheological models better correspond to the experimental curves measured on soft viscoelastic biological tissues during their mechanical load and relaxation. Nowadays the most popular rheological models are 3-elemtns and 5-element passive models with 2(3) elastic and 1(2) viscous elements accordingly. The more complex model with one active element reacting additively on both strain and strain rate changes with two different time delay was found perfectly corresponding to the experimental studies on different viscoelastic samples. In the presented study the differences between dynamical behavior of the 3 and 5-element rheological models without/with time delay in the load/discharge experiments have been studied. It was shown, the time 
delay is essential to distinguish the realistic behavior of biological active (live) tissues. The constitutive relations for 3 -element and 5-element models without and with delay were obtained and studied for the linear strain load experiments. The obtained data were compared to the experimental curves measured on the vessel wall and heart tissues. The better correspondence is detected for the 5element curve that exhibit two-time relaxation, and for the model with delay.

Acknowledgement.The authors are grateful to the organizers and participants of the 3rd International conference "Differential Equations and Control Theory" (DECT-2018) for the interest to the topic and stimulating discussions.

\section{REFERENCES}

1. G. Bao, S. Suresh. Cell and molecular mechanics of biological material. Nature Materials, - 2003 - 2. - P. 715-725.

2. H. Fröhlich. Coherent Excitation in Active Biological Systems. In: F. Gutmann, H. Keyzer (eds). Modern Bioelectrochemistry. Springer, Boston, MA.,- 1986 - P. 241-261.

3. D. Saintillan, Rheology of Active Fluids. Annual Review of Fluid Mechanics, - 2018 - 1. 50. - P. 563-592.

4. M.C. Marchetti, J.F. Joanny, S. Ramaswamy, T.B. Liverpool, J. Prost, M. Rao, S.R. Aditi, Hydrodynamics of soft active matter. Reviews of Modern Physics, - 2013. - 3. 85. - P. 1143-1189.

5. V. Bratanov, F. Jenko, E. Frey, New class of turbulence in active fluids. Proceedings of the National Academy of Sciences,- 2015. - 49. 112. - P. 15048 15053.

6. S.R. Caplan, Autonomic energy conversion. II. An approach to the energetics of muscular contraction. Biophys J., - 1968. - 8. - P. 1167-1193.

7. S.A. Regirer, I.M. Rutkevich, P.I. Usik, Model of vascular tone. Mechanics of Polimers, - 1975. - 4. - P. 585-589.

8. N.Kh. Shadrina, V.A. Buchin, Mathematical Modeling of the Response of a Resistive Vessel to Pressure. Biophysics, - 2009. - 2. 54. - P. 188-192.

9. S.A. Regirer, N.Kh. Shadrina, A simple model of a blood vessel with the wall sensitive to mechanical stimuli. Biophysics, - 2002. - 5. 47. - P. 845-850.

10. N.N. Kizilova, E.N. Filippova, The model of arterial tree with autoregulation as viscoelastic chamber from bioactive material. Mechanics. The scientific research and study-methodology developments. Colleted articles of Gomel, 2014.-8. - P. 100-105. (in Russian). 
11. H. Philippova,N. Kizilova, The investigation of the flow of viscous fluid in the viscoelastic chamber from bioactive material. Reporter Of Kyiv National University of Taras Shevhenko. Series: "Physics and mathematics scienes", 2015. - 5. 47. - P. 845-850. (in Ukrainian).

12. E.N. Solovyova, N.N. Kizilova, The analysis of descrete models of bioactive soft and fluid materials. Colleted articles of XVIII International symposium "The methods of descrete singularities in problems of mathematical physics" (MDOZMF-2017). Kharkiv, - 2017. - P. 198-201. (in Russian).

13. N.N. Kizilova, E.N. Solovyova, The analysis of the rheology models of bioactive soft and fluid materials. Reporter of Kharkiv National University of V.N. Karazin. Ser. "Mathematical modelling. Thechnology of information. Automatization systems of control".- 2017. - 35. - P. 21-30. (in Russian).

14. T. Bronshtein, G.C.T. Au-Yeung,U. Sarig et al., A Mathematical Model for Analyzing the Elasticity, Viscosity, and Failure of Soft Tissue: Comparison of Native and Decellularized Porcine Cardiac Extracellular Matrix for Tissue Engineering. Tissue Eng Part C Methods. - 2013. - Aug. - 8. 19. - P. 620-630.

15. Y. Zhu, Y. Zheng, Y.-Y. Shen et al., Analyzing and modeling rheological behavior of liver fibrosis in rats using shear viscoelastic moduli. J Zhejiang Univ Sci B. - 2014. - Apr. - 4.15, - P. 375-381.

16. Biomechanics of Cells and Tissues. Experiments, Models and Simulations. P. Lecca (Ed.), - 2013. - 175 p.

17. Mechanics of Biological Tissue. G. A. Holzapfel, R. W. Ogden (eds.), Heidelberg: Springer-Verlag, - 2005. - 466 p.

18. P. Kochova, J. Klepacek, J. Hlubocky et al., Heart valve viscoelastic properties - a pilot study. Applied and Computational Mechanics,-- 2007. - 1. - P. 97-104.

Соловйова О. М., Кізілова Н. М. Математичне моделювання біоактивної артеріальної стінки. Біологічно активні матеріали - це біологічні тканини або штучні матеріали, які можуть виконувати механічну роботу за рахунок хімічних реакцій, конфірмаційних змін, формування мікро - та мезоструктури та реконструкції. Таких матеріалів багато у біологічних організмах, таких як скелетні, гладкі та серцеві м'язи, джгутики та вії в бактеріях, цитоскелет і молекулярні мотори в клітинах.Біологічні тканини та їх штучні замінники складаються з різних волокон і мають складні в'язко-пружні властивості. Відповідність матеріальних параметрів природних та інженерних матеріалів при різних режимах навантаження та релаксації має важливе значення для їх успішної та тривалої роботи. Перша математична модель активного біологічного матеріалу була запропонована А. Хіллом у вигляді гіперболічного зв'язку між напругою (або навантаженням) в м'язі та його активна швидкість стиснення. В роботі розглянуті найпопулярніші 3-елементні та 5-елементні реологічні моделі м'яких тканин людини як в'язкопружні тіла, що враховують затримку часу між навантаженням та механічним відгуком матеріалу. Затримка часу стосується лише активних (живих) біологічних матеріалів. В роботі моделюється активний 
відгук як додаткова лінійна в'язко-еластична реакція на швидкість деформації та деформації матеріалу. У біологічних тканинах такий відгук забезпечується різними датчиками i, таким чином, моделюється різними затримками часу. Отримані та досліджені рівняння для 3-елементних та 5-елементних моделей без затримки і з затримкою часу, та вивчені для лінійних деформацій при експериментах. Відмінності між моделями описуються в термінах навантаження-релаксація кривих. Отримані дані порівнювались 3 експериментальними кривими отриманними на стінкці судин і тканинах серця. Краща відповідність була отримана для 5-елементної кривої, яка демонструє дворазову релаксацію, і для моделі з затримкою.

Ключові слова: активні біоматеріали; в'язкопружні рідини; математичне моделювання.

H. N. Solovyova, N. N. Kizilova. Mathematical modeling of bioactive arterial wall. Bioactive materials are biological tissues or artificial materials that can perform a mechanical work at the expense of chemical reactions, conformational changes, micro- and mesostructure formation and remodeling. Such materials are abound in biological organisms like skeletal, smooth and cardiac muscles, flagella and cilia in bacteria, cytoskeleton and molecular motors in the cells. Biological tissues and their artificial substitutes are composed by different fibers and possess complex viscoelastic properties. Correspondence of the material parameters of natural and engineered materials at different loading regimes and relaxation is essential for their successful and long time performance. The first mathematical model of the active biological material was proposed by A.Hill in the form of a hyperbolic relationship between the tension (or load)in the muscle and its active velocity of contraction. Here the most popular 3-element and 5-element rheological models of human soft tissues as viscoelastic bodies are considered accounting for the time delay between the load and mechanical respond of the material. The time delay is only proper to active (live) biological materials only. Here the active respond is modeled and the additive linear viscoelastic reaction to the strain and strain rate of the material. In the biological tissues such respond is provided by different sensors and, thus, is modeled by distinct time delays. The constitutive relations for 3-element and 5-element models without and with delay are obtained and studied for the linear strain applied experiments. The differences between the models are described in terms the load-relaxation curves. The obtained data compared to the experimental curves got on the vessel wall and heart tissues. The better correspondence is detected for the 5-element curve that exhibit two-time relaxation, and for the model with delay.

Keywords: active biomaterials; visoelastic fluids; mathematical modelling.

Article history: Received: 6 November 2018; Final form: 14 December 2018; Accepted: 16 December 2018. 